\title{
Recovery of Vanadium from Boiler Slag of Oil Fired Power Plant
}

by Naganori ROKUKAWA ${ }^{1}$

1. National Research Institute for Pollution and Resources, MITI, Onogawa, Tsukuba 305

Extraction of vanadium from boiler slag derived from oil fired power plant was carried out by water leaching of heated sample under addition of sodium hydroxide. Salting out and crystallization of vanadate salt from leaching liquor was done with the addition of ammonium chloride and ethanol.

In the water leaching using the addition of sodium hydroxide and heating, vanadium was effectively extracted from boiler slag. For instance, the extraction ratio of vanadium was 99.9 percent when the sample heated for $120 \mathrm{~min}$ at $120^{\circ} \mathrm{C}$ with $6 \mathrm{ml} / \mathrm{g}$-slag of $50 \% \mathrm{NaOH}$ solution was leached by water for $60 \mathrm{~min}$ at $25^{\circ} \mathrm{C}$.

In the salting out of vanadium with addition of ammonium chloride to the leaching liquor, the deposit obtained at $\mathrm{pH} 8.36$ was identified as ammonium metavanadate, $\mathrm{NH}_{4} \mathrm{VO}_{3}$. On the other hand, in the case of addition of ethanol, the deposit was crystalized as sodium vanadate, $\mathrm{NaVO}_{3} \cdot 2 \mathrm{H}_{2} \mathrm{O}$.

KEY WORDS: Boiler Slag, Vanadium, Caustic Leaching, Vanadate Salt, Crystallization

\section{1. 緒言}

原油中にはバナジゥム，ニッケルなどの金属成分が微量含まれ ている ${ }^{1) 2)} こ と か ゙$ 知られており，原油中に含まれる金属成分の大 部分は蒸溜残渣油 (重油) に濃縮され ${ }^{3}$ ), 重油専焼火力発電所等 の燃焼灰あるいはボイラスラグに含まれて排出される。

重油燃焼灰またはボイラスラグ中に含まれるバナジウム，ニッ ケルなどの金属成分を回収する方法については，特許として数多 くの提案がされているが，工業的には，ソーダ灰(炭酸ナトリウ ム）を加えて酸化焙焼して, バナジウムを可溶性塩に変えて, 温 水で浸出し, 浸出液にアンモニウム塩を添加して, バナジウムを バナジン酸アンモニウムとして回収する方法が実施されてい $3^{4) \sim 7)}$ にすぎない。しかし, ソーダ焙焼法は焙焼温度が $1,000{ }^{\circ} \mathrm{C}$ 前後の高温で行われるため, エネルギーコストが高く, 経済的な 抽出法の開発が期待されている。

著者は, すでに重油然焼灰からのバナジウムとニッケルの回収 を目的として, 硫酸添加加熱による水浸出 ${ }^{8)}$ および溶媒抽出法に よる浸出液からのバナジゥムとニッケルの分離 ${ }^{9)}$ について検討し てきた。本報告ではボイラスラグからのバナジウムの回収を目的 として, カセイソーダ（水酸化ナトリウム）溶液を添加加熱後, 水浸出する方法および浸出液に塩化アンモニウムまたはエタノー ルを添加してバナジン酸塩を析出させる方法を検討したので，そ の結果について報告する。

* 1990 年 8 月 21 日受付 1991 年 1 月 28 日受理 日本鉱業会昭和 63 年度春季大会において一部発表

1. 正会員 公害資源研究所材料資源部

キーワード: ボイラスラグ,バナジウム,カ性浸出, バナジン酸塩， 晶析
Table 1 Chemical analysis of oil-fired boiler slag.

(wt \%)

\begin{tabular}{c|c|c|c|c|c|c|c}
\hline $\mathrm{V}$ & $\mathrm{Ni}$ & $\mathrm{Fe}$ & $\mathrm{Mg}$ & $\mathrm{Ca}$ & $\mathrm{Si}$ & $\mathrm{Al}$ & $\mathrm{S}$ \\
\hline 28.4 & 4.89 & 4.46 & 3.92 & 0.05 & 0.65 & 0.24 & 5.66 \\
\hline
\end{tabular}

\section{2. 試料および実験方法}

\section{$2 \cdot 1$ 試料}

試料として用いたボイラスラグは重油専焼火力発電所のボイラ から排出された，やや褐色を呈した灰黒色の溶融固化した塊状あ るいは板片状のものであり,これを $200 \mathrm{mesh}(74 \mu \mathrm{m})$ 以下に粉砕 したものを使用した。試料の主な成分の化学分析值を表 1 に示す。

\section{$2 \cdot 2$ 試薬}

試薬はすべて市販の特級試薬を使用し，スラグの添加に使用し たカセイソーダ $(\mathrm{NaOH})$ は潮解性であることから, 固体で取扱 うことは困難であり, また, 水に溶解すると発熱し, その水溶夜 は $\mathrm{NaOH}$ 濃度が高くなるに従って, 粘性が増加し, 流動性が低下 することから，スラグへの添加および取扱いやすさを考慮して， $\mathrm{NaOH}$ 濃度 $50 \%$ (W/V)の;水溶液を使用した。

\section{$2 \cdot 3$ 抽出}

抽出試験は容量 $100 \mathrm{~m} l$ の超硬質ガラスびん（DURAN 製）に試 料を採取し, $50 \%$ のカセインーダ溶液を所定量添加して, 定温恒 温器に入れて所定時間加熱し, 次に所定の固液濃度になるように 水を加えて，マグネチックスターラにより所定時間 $400 \mathrm{rpm}$ (長 さ $30 \mathrm{~mm}$ ，高さ $7.5 \mathrm{~mm}$ のオクタゴン型回転子）で䚓拌後，ろ過し， ろ夜を分析して各金属成分の抽出率を求めた。

\section{$2 \cdot 4$ バナジン酸塩の析出}

アンモニウム塩添加によるバナジン酸塩の析出は, 浸出液の $\mathrm{pH}$ 
を塩酸により所定 $\mathrm{pH}$ 調整後, 塩化アンモニウム $\left(\mathrm{NH}_{4} \mathrm{Cl}\right)$ を直 接添加して所定時間擤拌後, ろ過し，ろ液を分析して析出率を求 めた。

また，有機溶媒添加によるバナジン酸塩の析出は，浸出液にエ タノール $(\mathrm{EtOH})$ を所定量添加して, 所定時間鯢拌後, ろ過し, ろ液を濃縮乾固後, 乾固物を塩酸で溶解して, 溶解したバナジウ ムを定量して析出率を求めた。

\section{$2 \cdot 5$ 分析}

金属イオンの定量は原子吸光光度計（日立180-50 型）により 測定し，試料および析出物等の化合物の同定はX線回折装置 (理 学電機ガイガーフレックス RAD-II A 型 ) により行った。

\section{3. 結果および考察}

\section{3・1 カセイソーダ添加加熱による水漫出}

$\mathrm{NaOH}$ 濃度 $20,40,60$ および $100 \mathrm{~g} / l$ 溶液により, 固液濃度 $20 \mathrm{~g}$ $l l$, 浸出温度 $60^{\circ} \mathrm{C}$ で $60 \mathrm{~min}$ 浸出したときのバナジウムの抽出率 はそれぞれ $29.9 ， 36.5 ， 43.5$ および $47.1 \%$ であった。

一方, 試料 $1 \mathrm{~g}$ 当たり $50 \% \mathrm{NaOH}$ 水溶液を $2,4,6$ および $10 \mathrm{~m} l$ 添加し, $120^{\circ} \mathrm{C} て ゙ 60 \mathrm{~min}$ 加熱し，それぞれの固液濃度が $20 \mathrm{~g} / l$ に なるように水を加えて, $60^{\circ} \mathrm{C} て ゙ 60 \mathrm{~min}$ 浸出したときのバナジウム の抽出率はそれぞれ54.3，86.8，99.8 および96.8\%であった。

なお，浸出液の $\mathrm{pH}$ は, $\mathrm{NaOH}$ 添加加熱の場合12.87から13.57， 直接浸出の場合 13.04 から 13.62 範囲であった。

スラグにカセイソーダを少量添加して加熱後，水浸出すること により, バナジウムの抽出率は著しく向上し，また，浸出液の $\mathrm{pH}$ もそれぞれわずかに低下したことから，試料中のバナジゥム化合 物は $\mathrm{NaOH}$ 添加して加熱することにより, $\mathrm{NaOH}$ と反応して水 に可溶性の化合物に転換されるものと考えられる。

試料 $1 \mathrm{~g}$ 当たり $50 \% \mathrm{NaOH}$ 溶液を $6 \mathrm{ml}$ を添加し, $120^{\circ} \mathrm{C}$ で加熱 し, 固液濃度 $20 \mathrm{~g} / l, 25^{\circ} \mathrm{C}$ で $60 \mathrm{~min}$ 浸出したときの加熱時間とバ ナジゥムの抽出率の関係を図 1 に示す。

バナジウムの抽出率は加熱時間 $60 \mathrm{~min}$ でほぼ一定となり，120 $\min$ で $99.9 \%$ あった。なお, 図には示していないが, ニッケル と鉄の抽出率は加熱時間にほとんど影響されず，カルシゥムは加 熱時間が増加するに従って抽出率がわずかに低下し, $120 \mathrm{~min}$ での ニッケル，鉄およびカルシウムの抽出率はそれぞれ 0.02\%，0.03\% および $0.05 \%$ と低く, アルミニウムの抽出率は $15 \mathrm{~min} て ゙ 49.9 \%$ ， $90 \mathrm{~min}$ で $80.6 \%$ と加熱時間が増加するに従って高くなった。

試料 $1 \mathrm{~g}$ 当たり $50 \% \mathrm{NaOH}$ 溶液を $6 \mathrm{ml}$ を添加し, 所定温度で 60

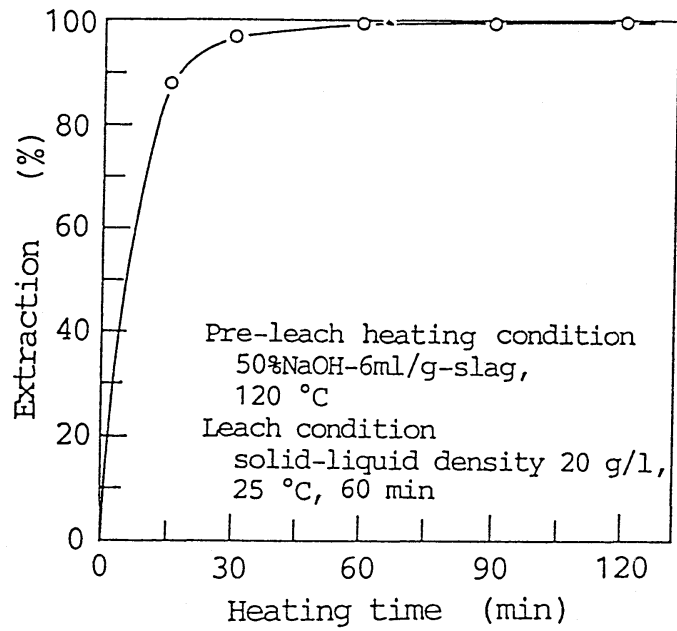

Fig. 1 Effect of pre-leach heating time on extraction of vanadium.

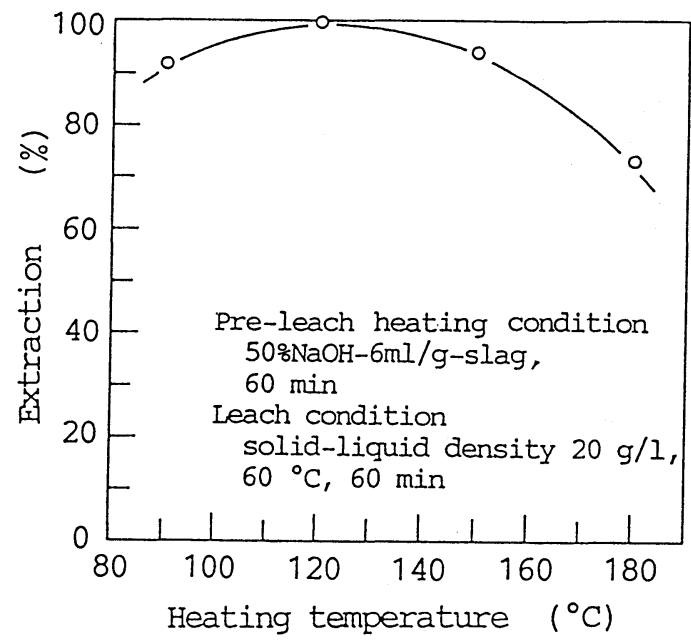

Fig. 2 Effect of pre-leach heating temperature on extraction of vanadium.

$\min$ 加熱後, 固液濃度 $20 \mathrm{~g} / l$, 浸出温度 $60^{\circ} \mathrm{C}$ で $60 \mathrm{~min}$ 浸出したと きの加熱温度とバナジウムの抽出率の関係を図 2 に示す。

バナジウムの抽出率は加熱温度 $120^{\circ} \mathrm{C}$ で $99.8 \%$ となり, そのと きの他の金属イオンの抽出率はNi 0.05\%, $\mathrm{Fe} 0.04 \%, \mathrm{Ca} 0.01 \%$ ， $\mathrm{Mg} 0.76 \%$ およびA1 76.7\%とアルミニウム以外は $1 \%$ 以下であった。 アルミニウムの抽出率は高くなったが，その抽出量注試料中の含 有量が低いためバナジウムの抽出量の $1 / 157$ であった。

浸出液の $\mathrm{pH}$ は加熱温度が高くなるに従って低下したが， $90{ }^{\circ} \mathrm{C}$ と $180^{\circ} \mathrm{C}$ との $\mathrm{pH}$ 差は 0.2 とわずかで, $120^{\circ} \mathrm{C} て ゙$ 加熱したときの浸 出夜の $\mathrm{pH}$ H13.38であった。なお, 浸出夜の色は無色であった。

溶液中のバナジウムは $\mathrm{pH}$ によりイオンの形態が異なることが 知られており， $\mathrm{pH} 10.6$ 以上の強了ルカリ性溶液中では，オルト 酸イオン $\left(\mathrm{VO}_{4}{ }^{3-}\right)$ として存在する ${ }^{10}$ ことから, 浸出液中のバナジ ウムは $\mathrm{VO}_{4}^{3-}$ イオンの状態で溶解しているものと考えられる。

カセイソーダ添加加熱試料を固液濃度 $20 \mathrm{~g} / l, 25^{\circ} \mathrm{C}$ で浸出した ときの浸出時間とバナジゥムの抽出率の関係を図 3 に示す。

浸出時間 $15 \mathrm{~min}$ で, Vの抽出率は $99.2 \%$ と短時間で抽出された。 なお, $\mathrm{Ca}$ の抽出率は $15 \mathrm{~min}$ で $1.06 \%, 120 \mathrm{~min}$ で $0.57 \%$ と浸出時 間が増加するに従ってわずかに減少した。

カセイソーダ添加加熱試料を固液濃度 $20 \mathrm{~g} / l$ で $60 \mathrm{~min}$ 水浸出 したときの浸出温度とバナジゥムの抽出率の関係を図 4 に示す。 バナジウムの抽出率は浸出温度が高くなるに従ってわずかに低

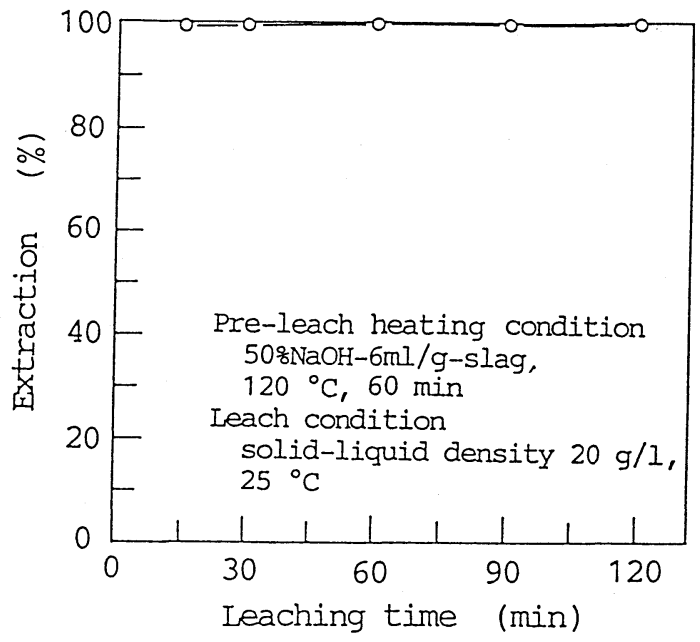

Fig. 3 Effect of leaching time on extraction of vanadium. 


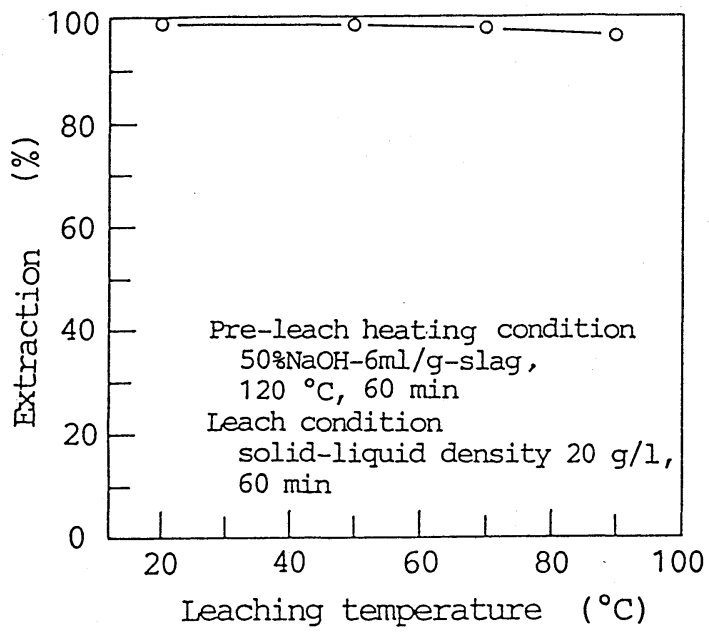

Fig. 4 Effect of leaching temperature on extraction of vanadium.

下し，浸出温度 $25^{\circ} \mathrm{C}$ で $98.9 \% ， 90^{\circ} \mathrm{C} て ゙ 96.2 \%$ あったことから， 浸出温度は常温で十分であるものと考えられる。

なお，鉄，アルミニウムの抽出率は浸出温度が高くなるに従っ てわずかに増加し, カルシウム, マグネシウムは減少したがその 值は非常にわずかであった。

浸出温度が高くなるに従ってバナジウムの抽出率が低下するの は，いったん溶解した $\mathrm{VO}_{4}^{3-}$ イオンがわずかに溶解した $\mathrm{Ca}^{2+}$ イオ ンと反応して不溶性の $\mathrm{CaVO}_{3}$ が生成するためと考えられる。

試料 $1 \mathrm{~g}$ 当たり $50 \% \mathrm{NaOH}$ 溶液 $5 \mathrm{~m} l$ を添加し, $120{ }^{\circ} \mathrm{C}$ で $60 \mathrm{~min}$ 加熱後, 所定の固液濃度になるように水を加えて, $25^{\circ} \mathrm{C} て ゙ 60 \mathrm{~min}$ 浸出したときの固液濃度とバナジウムの抽出率の関係を図5に示す。 固液濃度が $15.4 \mathrm{~g} / l$ から $40 \mathrm{~g} / l$ の範囲では, 固液濃度の影響は ほとんどなく, バナジウムの抽出率の差は $1.7 \%$ であった。これは カセインーダ添加量比 $(\mathrm{NaOH}$ 添加量 $-\mathrm{m} l / \mathrm{g}$ - 試料) が同じであ るためと考光られる。浸出液の $\mathrm{pH}$ は固液濃度 $10 \mathrm{~g} / l$ で $13.52,40$ $\mathrm{g} / l$ で13.80であった。

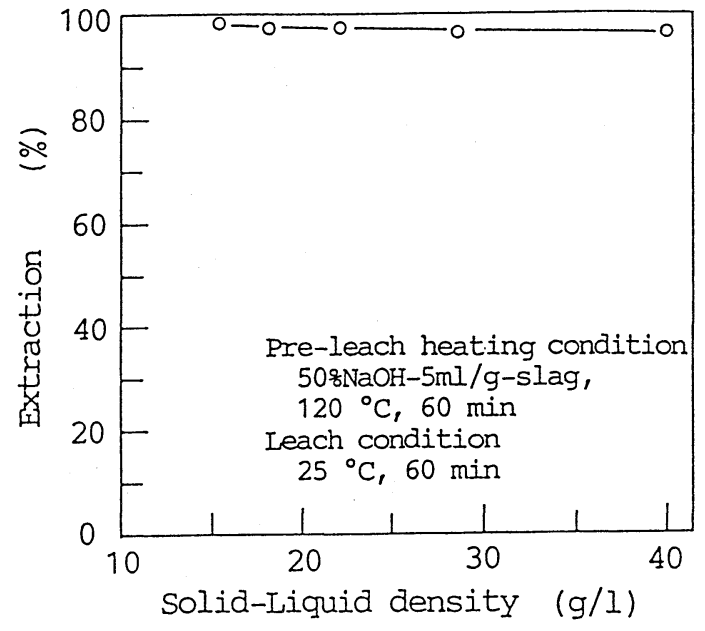

Fig. 5 Effect of solid-liquid density on extraction of vanadium.

ボイラスラグ中のバナジウムの形態については，バナジウムは 燃焼ガス中でまず $\mathrm{V}_{2} \mathrm{O}_{3}, \mathrm{~V}_{2} \mathrm{O}_{4}$ になり，最終的には $\mathrm{V}_{2} \mathrm{O}_{5}$ となり， 油中の $\mathrm{Na}, \mathrm{S}$ がこれと作用して非常に複雑な化合物となる ${ }^{11)}$ とい われているが，X線回折等により同定された化合物の報告はほと んど見あたらない。また，ボイラスラグ中の化合物の形態につい ては, 重油の種類, 燃焼条件によっても異なるものと考えられて いるにすぎない。

ボイラスラグおよびスラグに $\mathrm{NaOH}$ 溶液を添加加熱した加熱物 のX線回折図を図6に示す。

$\mathrm{X}$ 線回折によるコンピュータ検索 (理学電機 $\mathrm{RAD}-\mathrm{C}$ データ処 理システム)により推定された化合物は $\mathrm{NaV}_{6} \mathrm{O}_{15}(\mathrm{JCPDS}$ フ イル No 241155, 信頼性係数R. $\mathrm{F} 136$ ), $\mathrm{FeVO}_{4}$ (No 300667 , R.F 125 )， $\mathrm{Ca}_{0.17} \mathrm{~V}_{2} \mathrm{O}_{5}$ (No 261165, R.F 120 ) および $\mathrm{Mg} \mathrm{SO}_{4}$ - $6 \mathrm{H}_{2} \mathrm{O}$ ( No 240719, R.F 52 ) であった。なお, $\mathrm{MgSO}_{4}$. $6 \mathrm{H}_{2} \mathrm{O}$ については, ボイラ内の高温腐食防止のために重油に水酸 化マグネシウムを添加して燃焼しているため, $\mathrm{Mg}(\mathrm{OH})_{2}$ が $\mathrm{SO}_{2}$

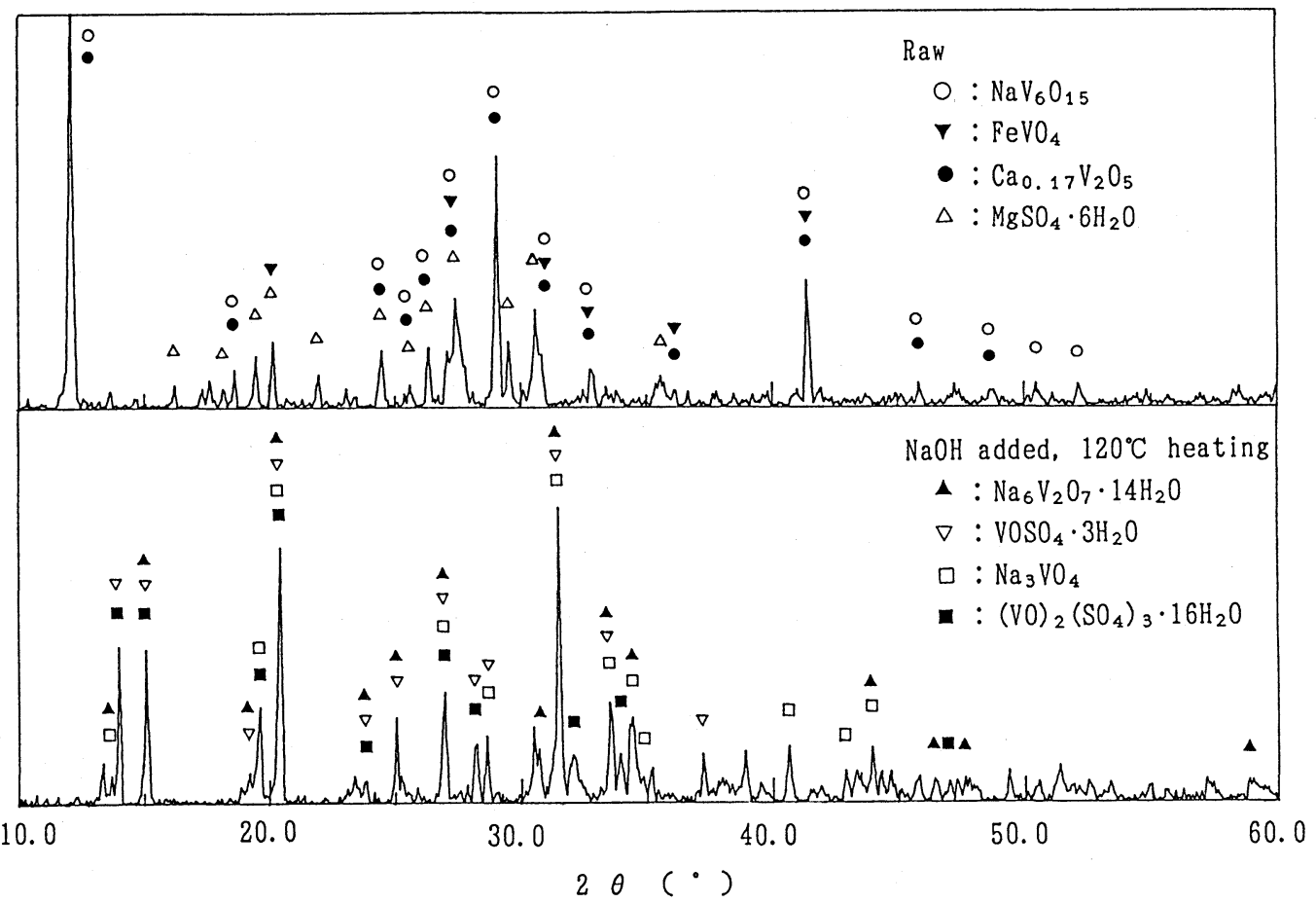

Fig. 6 X-ray diffraction patterns of oil-fired boiler slag $(\mathrm{CuK} \alpha, 35 \mathrm{KV}-20 \mathrm{~mA}, 2000 \mathrm{cps})$. 
と次のように反応して,

$\mathrm{Mg}(\mathrm{OH})_{2}+\mathrm{SO}_{2}+5 \mathrm{H}_{2} \mathrm{O} \rightarrow \mathrm{MgSO}_{3} \cdot 6 \mathrm{H}_{2} \mathrm{O} \cdots \cdots \cdots$ (1)

$\mathrm{MgSO}_{3} \cdot 6 \mathrm{H}_{2} \mathrm{O}+1 / 2 \mathrm{O}_{2} \rightarrow \mathrm{Mg} \mathrm{SO}_{4} \cdot 6 \mathrm{H}_{2} \mathrm{O} \cdots \cdots \cdots \cdots(2)$

生成したものと考えられる。

また, 試料 $1 \mathrm{~g}$ 当たり $50 \% \mathrm{NaOH}$ 溶液 $5 \mathrm{ml}$ を添加して, $120^{\circ} \mathrm{C}$ で加熱し, 水分を蒸発させたときの加熱物は, $\mathrm{Na}_{6} \mathrm{~V}_{2} \mathrm{O}_{7} \cdot 14 \mathrm{H}_{2} \mathrm{O}$ ( No 241443, R.F 116 ), $\mathrm{VOSO}_{4} \cdot 3 \mathrm{H}_{2} \mathrm{O}$ (No 270950, R.F 79), $\mathrm{Na}_{3} \mathrm{VO}_{4}$ ( No 281174, R.F 49), ( $\left.\mathrm{VO}\right)_{2}\left(\mathrm{SO}_{4}\right)_{3} \cdot 16 \mathrm{H}_{2} \mathrm{O}$ (No 10323 , R.F 44) が推定された。ボイラスラグ中で, $\mathrm{V}_{2} \mathrm{O}_{5}$ として 存在するバナジウム化合物の一部抢よび $\mathrm{FeVO}_{4}$ はカセイソーダと 次のように反応して，

$\mathrm{V}_{2} \mathrm{O}_{5}+6 \mathrm{NaOH} \rightarrow 2 \mathrm{Na}_{3} \mathrm{VO}_{4}+3 \mathrm{H}_{2} \mathrm{O}$ (3)

$\mathrm{FeVO}_{4}+3 \mathrm{NaOH} \rightarrow \mathrm{Na}_{3} \mathrm{VO}_{4}+\mathrm{Fe}(\mathrm{OH})_{3}$ (4)

水に可溶性の $\mathrm{Na}_{3} \mathrm{VO}_{4}$ が生成されるものと考えられる。ボイラス ラグにカセイソーダ溶液を添加して加熱することにより， バナジ ウム化合物は水に可溶な塩に変わり，水に容易に溶解するものと 考えられる。

なお, スラグに $\mathrm{NaOH}$ 溶夜を少量添加して加熱し，加熱物を水 浸出する方法は, $\mathrm{NaOH}$ 溶液で直接浸出する方法に比べて，バナ ジウムを効率よく抽出することができることから，有効な抽出法 であるものと考えられる。

\section{$3 \cdot 2$ 漫出液からのバナジン酸塩の析出}

バナジン酸塩を含むアルカリ溶夜にアンモニウム塩を添加する とバナジン酸アンモニウムが析出することが古くから知られてお り, 重油専焼火力発電所のボイラから排出されたスラグをソーダ 焙焼した浸出液からのバナジウムの回収が，工業的にも実施され ている。しかし，カセイソーダ浸出液からバナジウムを回収する 方法については不明な点が多い。

著者らは，バナジウムを含むアンモニア性アルカリ溶液からの バナジン酸塩の析出を検討 ${ }^{12)}$ ᄂ, 塩析剤としては塩化アンモニウ ムが適当であり，溶液の pHは 7 から 9 の範囲が有効であることを 明らかにしてきた。

スラグに $\mathrm{NaOH}$ 添加加熱し，水浸出した浸出液を $\mathrm{HC} 1$ で $\mathrm{pH}$ 8.51 に調整した V 濃度 $2.80 \mathrm{~g} / l$ を含む溶液に $\mathrm{NH}_{4} \mathrm{C} 1$ を $100 \mathrm{~g} / l$ になるように添加したときの反応時間とバナジゥムの析出率の関 係を図7に示す。

アンモニウム塩を添加してバナジン酸塩を析出させる場合，平 衡に達するのに時間がかかることが知られているが，バナジウム の析出率は反応時間 $1 \mathrm{hr}$ で $91.2 \%, 4 \mathrm{hr}$ で $94.1 \%$ となり時間の経

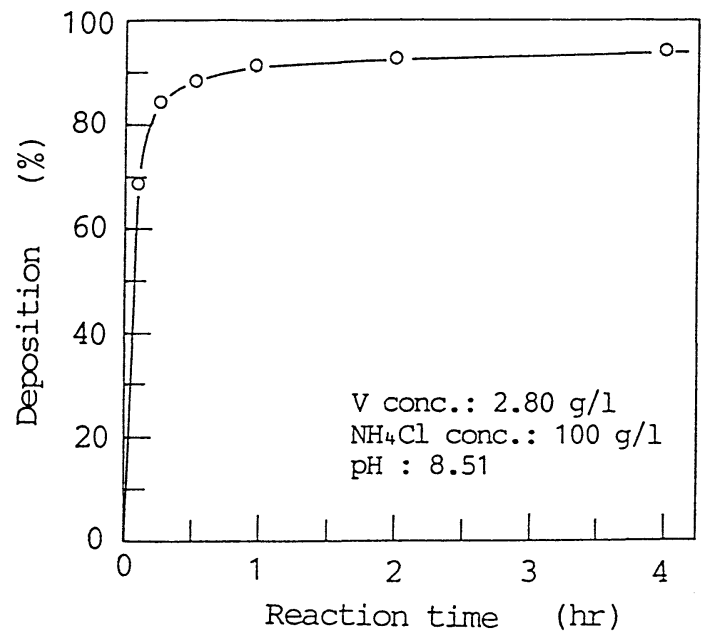

Fig. 7 Effect of reaction time on deposition of vanadium.

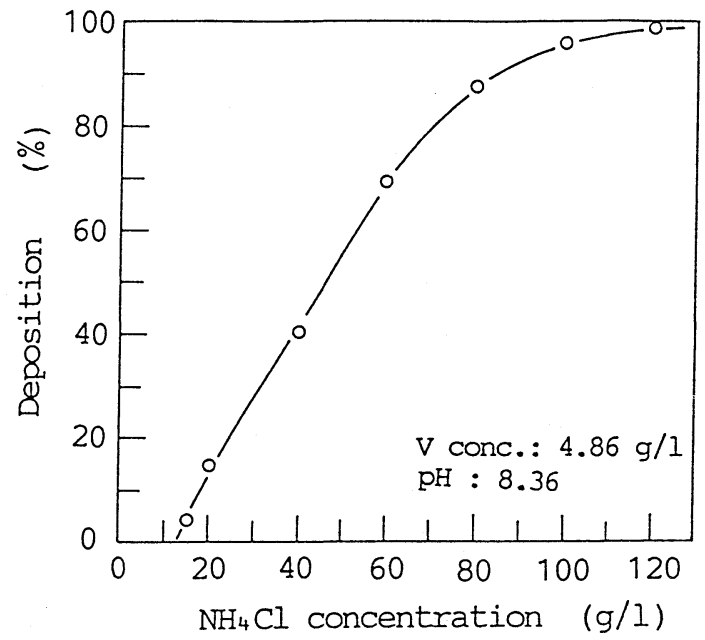

Fig. 8 Effect of ammonium chloride concentration on deposition of vanadium.

過とともにわずかに増加し, $8 \mathrm{hr} て ゙ 95.4 \%, 24 \mathrm{hr}$ で $96.2 \%$ あっっ た。

カセイソーダを添加加熱し, 水浸出した浸出液を $\mathrm{HC} 1$ で $\mathrm{pH}$ 8.5 に調整し, 沈殿物をろ別した $\mathrm{pH} 8.36, \mathrm{~V}$ 濃度 $4.86 \mathrm{~g} / l$ 溶液に $\mathrm{NH}_{4} \mathrm{Cl}$ を添加し, $60 \mathrm{~min}$ 観拌し, $24 \mathrm{hr}$ 静置したときの塩化ア ンモニウム濃度とバナジウムの析出率の関係を図 8 に示す。

バナジウムの析出率は $\mathrm{NH}_{4} \mathrm{C} 1$ 濃度が増加するに従って高くな り , $\mathrm{NH}_{4} \mathrm{Cl}$ 添加濃度 $120 \mathrm{~g} / l$ で $98.4 \%$ であった。 $\mathrm{NH}_{4} \mathrm{Cl}$ 濃度 10 $\mathrm{g} / l$ 以下ではバナジゥムは全く析出されなかった。

しかし, $\mathrm{NaVO}_{3}$ を水に溶解した V 濃度 $5 \mathrm{~g} / l$ 溶液からのバナジ ウムの析出率は, $\mathrm{NH}_{4} \mathrm{Cl}$ 濃度 $10 \mathrm{~g} / l$ で $70 \%, 20 \mathrm{~g} / l$ で $95 \%, 40$ $\mathrm{g} / l$ で $98 \%$ であったことから, $\mathrm{NaOH}$ 添加加熱によるボイラスラ グ浸出液からバナジゥムを析出させるには, $\mathrm{NaVO}_{3}$ 単独溶液に比 べて, $\mathrm{NH}_{4} \mathrm{C} 1$ を多く必要とした。

なお，析出したバナジン酸塩は白色で，X線回折により，バナ ジン酸アンモニウム $\left(\mathrm{NH}_{4} \mathrm{VO}_{3}\right)$ が同定された。

ニッケル，コバルト，銅等の金属塩を含む硫酸酸性溶液に低級 アルコール等の水に可溶な有機溶媒を添加すると金属塩が析出す ることが知られており，著者らはすでにモリブデン酸塩を含むア

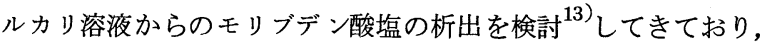
ボイラスラグのカセイソーダ浸出液からのバナジウムの析出に有 機溶媒添加の適用を検討した。

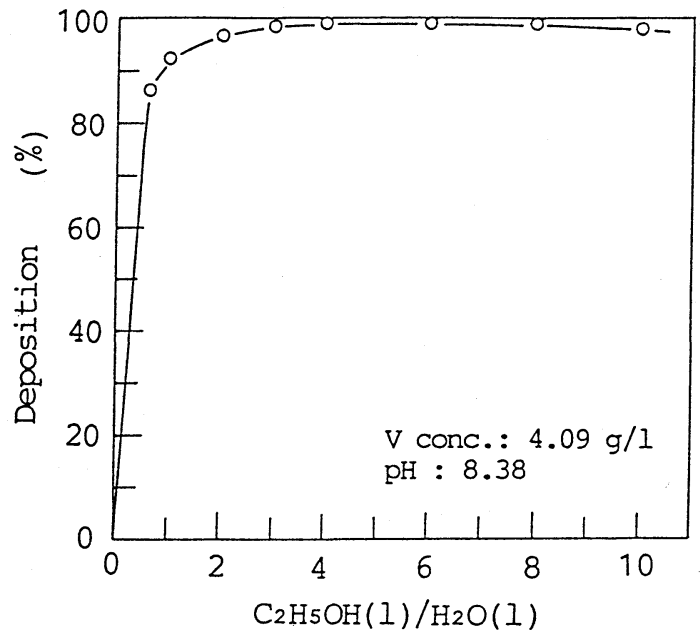

Fig. 9 Effect of added amount of ethanol on deposition of vanadium. 


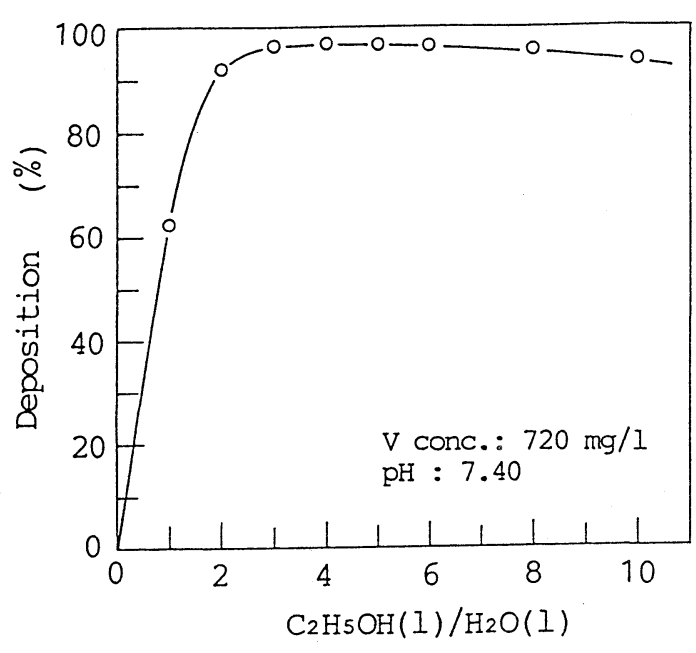

Fig. 10 Effect of added amount of ethanol on deposition of vanadium.

$\mathrm{pH} 8.38$ に調整し, $\mathrm{V}$ 濃度 $4.09 \mathrm{~g} / l$ を含むカセイセーダ浸出液に エタノール $(\mathrm{EtOH})$ を添加して, $25^{\circ} \mathrm{C} て ゙$ ボジン酸塩を析出させ たときの EtOH添加量とバナジウムの析出率の関係を図9に示す。 バナジウムの析出率は溶液に対する $\mathrm{E} t \mathrm{OH}$ 添加量比 ( E t OH /

$\left.\mathrm{H}_{2} \mathrm{O}\right)$ が 1 近くまでは急激に増加し，4 と6 ではそれぞれ $99.03 \%$ と $99.04 \%$ であった。EtOH添加量比 7 以上で, バナジウムの析出 率がわずかに低下するのは,バナジウムの析出物が EtoH に再溶 解するものと考えられる。

従って, 浸出液にEtOH を添加して, バナジン酸塩を析出させ るための $\mathrm{EtOH}$ 添加量比は 4 から 6 の範囲が有効であるものと考 えられる。なお, 白色をした析出物はX線回折により, バナジン 酸ナトリウム二水和物 $\left(\mathrm{NaVO}_{3} \cdot 2 \mathrm{H}_{2} \mathrm{O}\right)$ が同定された。なお, 溶

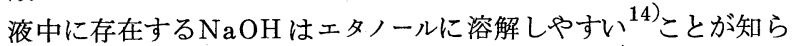

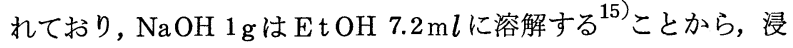
出液中の $\mathrm{NaOH}$ 濃度では析出されないものと考光られる。

なお，浸出液に $\mathrm{NH}_{4} \mathrm{Cl}$ を添加して $\mathrm{NH}_{4} \mathrm{VO}_{3}$ を析出させてろ過し， $\mathrm{V}$ を $720 \mathrm{~m} \mathrm{~g} / \mathrm{l}$ を含む $\mathrm{pH} 7.40$ の溶液に $\mathrm{EtOH}$ t添加してバナジン 酸塩を析出させたとさの $\mathrm{EtOH}$ 添加量とバナジウムの析出率の関 係を図 10 に示す。

バナジウムの析出率は $\mathrm{EtOH}$ 添加量比 4 で $97.0 \%$ と最大となり, $\mathrm{V}$ 濃度 $4.09 \mathrm{~g} / l$ の場合とほぼ同じような析出傾向を示した。析出 物はX線回折により, $\mathrm{NaCl}$ と $\mathrm{NH}_{4} \mathrm{VO}_{3}$ が同定された。 $\mathrm{NaCl}$ は 浸出液の $\mathrm{pH}$ を $\mathrm{HCl}$ で調整するとき, 溶液中の $\mathrm{NaOH}$ と $\mathrm{HCl}$ 济反
応して生成されたものと考光られ，EtOHを添加することにより，

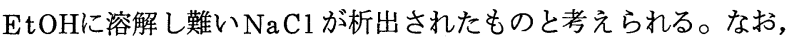
$200 \mathrm{~g} / l \mathrm{NH}_{4} \mathrm{Cl}$ 溶液に E tOH を添加しても $\mathrm{NH}_{4} \mathrm{Cl}$ は全く析出さ れなかった。

\section{4. 結}

重油専焼火力発電所から排出されるボイラスラグからのバナジ ウムの回収を検討した。

その結果, ボイラスラグにカセイソーダを少量添加して加熱後, 水浸出することにより，バナジウムを効率よく抽出することが可 能であった。例えば, 試料 $1 \mathrm{~g}$ 当たり $50 \% \mathrm{NaOH}$ 溶液 $6 \mathrm{ml}$ 添加し て, $120^{\circ} \mathrm{C}$ で $120 \mathrm{~min}$ 加熱後, 固液濃度 $20 \mathrm{~g} / l$ になるように水を加 えて, $25^{\circ} \mathrm{C} て ゙ 60 \mathrm{~min}$ 浸出したときの, バナジウムの抽出率は 99.9 \%であった。

また, 浸出液の $\mathrm{pH}$ HClにより調整して,塩化アンモニウムま たはェタノールを添加することにより，バナジン酸アンモニウム またはバナジン酸ナトリウムとしてそれぞれ析出させ, バナジゥ ムをバナジン酸塩として回収することが可能であった。

なお, 本研究に使用したボイラスラグは鹿島北共同発電(株)の 関係各位のご厚意により提供していただいたもので，ここに深く 感謝の意を表する。

\section{参考文 献}

1) Jones, M. C. \& Hardy, R. L. : Ind. Eng. Chem., 44 [11], 2615 2619, (1952)

2) Baker, E.W.: J. Chem. Eng. Data, 9[2], 307 308, (1964)

3）井口允生 : 燃料協会誌, 48 [511], 792 805, (1969)

4) 富田正夫 : 工業レアメタル $65,94 \sim 95,(1978)$

5）須藤欽吾 : 日本鉱業会誌, 97 [1122], 832 835, (1981)

6) 塚越邦光 : 日本釷業会昭和 61 年度秋季大会, 分科研究会資料, Q-5, $20 \sim 23,(1986)$

7）梅津良昭・戸沢一光 : 日本釷業会昭和 62 年度秋季大会, 分科研究 会資料, $\mathrm{M}-12,43 \sim 46,(1987)$

8）六川暢了：資源処理技術，37[2]，63～69, (1990)

9）六川暢了: 公害, $25[5], 257 \sim 264,(1990)$

10）日本分析化学会編：周期表と分析化学，358 360，(1975)，丸善 (東京)

11）瀬尾正雄 : 石油学会誌, $5(2), 106 \sim 110,(1962)$

12）六川暢了・加藤 茂: 公害資源研究所彙報, 16 [4], 35 42, (1987)

13）六川暢了・加滕 茂 : 公害資源研究所彙報, 16 [1]，7～12, (1986)

14）日本化学会編：化学便覧 基礎編, 改訂 3 版, I-162, (1984), 丸善 (東京)

15）大木道則 - 大沢利昭 - 田中元治 -千原秀昭編集 : 化学大辞典, 1171, (1989), 東京化学同人 (東京) 